\title{
Bridging or bonding? Relationships between integration and media use among ethnic minorities in the Netherlands
}

\author{
ALLERD L. PEETERS and LEEN D'HAENENS
}

Abstract

This article will first of all present a brief literature review on media use and identity construction and integration. This overview will be given in light of two phenomena: The concepts of 'social quality' and 'cultural participation' and the role played by the media in this on the one hand, and the multicultural composition of Dutch society on the other. The present contribution looks at the four largest ethnic minority groups in the Netherlands: Turkish, Moroccan, Surinamese and Antillean youngsters (13 to 24-year-olds), and adults (25 years of age and above). The key issue is 'integration' with its six dimensions, among which the extent to which ethnic minorities endorse norms and values of Dutch society, and the minorities' motivation with respect to integration. We also focus on related features, such as religious outlook and linguistic fluency. The measure of participation or integration in Dutch society is related to the use of four kinds of media: Radio, television, print media, and the Internet. The present contribution addresses the following question: To what extent are, on the one hand, bonding (i. e., an immigrant's slant towards maintaining contacts with the 'homeland') or, on the other, bridging (i.e., the desire to familiarize oneself with Dutch society and to participate in it socially and culturally) predictors of media use among ethnic minorities? We will address the relative importance of these four media in terms of media time and their twofold 'bridging' and 'bonding' capacities; for each of these media we check the extent to which ethnic minorities favor media from their native country and use applications which focus on their country of origin or their own group.

Keywords: integration, media use, ethnic minorities, the Netherlands, bridging and bonding 


\section{Introduction: The media and 'bridging' and 'bonding'}

One characteristic of the mass media is that they can resolve cultural differences. However, they can also be used to preserve and support the culture and the identity of a specific ethnic-cultural group and to have the contribution of this group to society recognized.

The former function is based on the two-way communication between a specific group and society. The media, after all, provide information on society at large to members of ethnic-cultural groups. They thus voice current norms and values and present an image of life in a particular society. It is also due to these mass media that relations between groups (for example between the old and the young or between native people and ethnic minorities) can be established and maintained. This process has been called 'bridging social capital' by Putnam (2000) and is a prerequisite for social-cultural participation, since people need to acquire an understanding of other groups and to enter into relationships with other groups in society for integration to be at all possible. Integration in society is to be read as social-cultural participation, i. e., a process in which a group begins to get closer to society thanks to social contacts, adherence to comparable norms and values, the same language, etc. In short, the media play a significant role in the process of rapprochement.

The latter function of the media concerns communication within a given cultural group. The mass media can provide a group with information from its 'home country' in the group's own language, thus helping members of the group to establish and maintain relations within the group itself. Putnam (2000) calls this process 'bonding social capital'.

\section{Focus on the Netherlands}

'Bridging' and 'bonding', and the role of the mass media, are definitely not trivial topics, as is clear from the ever increasing multiformity of the population of the Netherlands in the last few years. Recent data of CBS, the Dutch Census Bureau, put the number of non-western ${ }^{1}$ immigrants in the Netherlands at 1,668,297 in 2004 (of whom 1,021,074 belong to the first generation and 647,223 to the second generation). About half of them originate from Turkey, Morocco, Surinam, and the Netherlands Antilles and Aruba, the others coming from other non-western countries. The non-western immigrant population has grown by $25 \%$ since 1995 , and it is estimated that by 2010 there will be 2 million non-western immigrants in the Netherlands. In the more remote future, in 2050, about 4 million non-western immigrants will be living in the Netherlands, according to CBS. In 2000 about half of the immigrants were first-genera- 
tion immigrants, and because of the rapid increase in the number of second-generation immigrants, the percentage of first-generation immigrants is expected to drop to $45 \%$ in 2050 .

\section{ICT versus other media}

The concepts of 'social capital' and 'social-cultural participation or integration' are closely linked to developments in the domain of ICT in the information or network society; they concern relations between individuals and social networks (Van Dijk, 2003). The norms of reciprocity and reliability which emerge from these relations can contribute to the wellbeing of each individual (Putnam, 2000). Thus the Internet gives surfers complete freedom in deciding which discussions they will follow or take part in. Websites such as www.maroc.nl, aiming primarily at immigrant surfers, and their discussion groups and chat rooms present a platform for 'bonding social capital', i.e., an opportunity for contacting likeminded people, so that the individual's own identity and the group's homogeneity can be strengthened. Turkish and Moroccan websites often give a great deal of prominence to Islam, and since people are aware that their input is largely anonymous, they feel they can freely discuss norms and values and social issues. As not only immigrant youngsters but also native young people take part in such discussions, this activity can result in mutual understanding and respect for each other's points of view, so that these websites can be said to build bridges between cultures. This is 'bridging social capital', because participants look beyond their own group and broaden their own identity.

Castells (1997), in his 'The Power of Identity', contrasts the individual's own identity with the global information society and the Internet, pointing out the loss of so-called legitimizing identity when faced with globalization and merging identities. The legitimizing identity is one's original identity, imposed by the dominant national institutions of society, for example, such as it is recorded in one's passport. Reacting to the loss of legitimizing identity, a resistance identity begins to develop; unfortunately, it offers no genuine solutions, it is defensive, it seeks its definition on the basis of exclusion and can take extreme forms such as religious fundamentalism or ethnic nationalism. Castells does have great expectations of a third type of identity, i.e., project identity, which emerges when social groups manage to build a new identity on the basis of whatever cultural medium, thus redefining and reshaping their position in the community. Here the media may find a new role, for they can help to create a new identity, no longer founding it on the current criteria of country of origin or ethnicity, but on the symbolic reality proffered via the media. 
This role is obviously not reserved for the Internet alone, a medium in which the user can also be the producer of the content, but it also includes the other media, which have a more rigid and permanent content. As far as radio and television are concerned, the public broadcasting system in the Netherlands aspires to make programs presenting a well-balanced image of all the people in our society and reflecting its multicultural nature. As an element of the Dutch public broadcaster's accountability, this aspiration has been laid down in a commitment included in the concessionary policy plan for $2000-2010^{2}$. The public broadcasting system as a whole, and each individual broadcasting organization, will have to make a visible effort to make this aspiration come true.

Continuous ratings research produces hardly any data on the media use of ethnic minority audiences in the Netherlands. Yet, to be able to prepare its programming policy for the next few years, the public broadcasting system needs more information about the access to and the appreciation of its programs (radio, television, and the Internet) among ethnic minorities. The public broadcasting system would like to know more about the media used by ethnic groups. NPS, a public broadcaster, has the task of offering a specific range of programs; it is under a statutory obligation to reserve $20 \%$ of its TV programs and $25 \%$ of its radio programs specifically for ethnic minorities. To this end NPS offers wideranging multicultural programs on radio and $\mathrm{TV}$, and has radio programs (on the station $747 \mathrm{AM}$ ) in several different languages.

Also newspaper editors have realized that, if they are to attract young ethnic minority readers, they will have to cover more news relevant to this particular ethnic group and to present it from an inclusive perspective, i. e., not only from the 'white man's' perspective, doing so for example in special supplements or in online versions. As a matter of fact, qualitative reception research undertaken by d'Haenens, Beentjes, and Bink (2000a; 2000b) among ethnic minority youngsters and adults, show that these groups are critical media users because they can compare media in the Netherlands with those in their country of origin, thus acquiring a wider view of the news. Moreover, their hunger for news and information about their own group as well as about their home country is only partly satisfied by the media in the Netherlands. This finding applies to all age groups; ethnic minorities have a strong need for information about their country of origin and turn to alternative means, especially foreign media, to find the news they are interested in. A third major finding is that immigrants do not identify with the image that Dutch media present of ethnic minorities as it is an image that they do not consider a fair reflection of the multicultural society of the Netherlands. This is another incentive for them to seek information in the me- 
dia from their home country. However, this is much less true of most young immigrants, who have often grown up in the Netherlands and are therefore used to the Western slant of news coverage in the media. As a result they do not feel the same need for media from their country of origin as their elders do. Generally speaking, ethnic minorities regard the one-sided approach to news about the immigrant population as particularly annoying and predominantly negative; positive news about ethnic groups is given too little emphasis.

Finally, the Internet, being an interactive medium, has a great potential for attracting users and readers from ethnic minorities. Since an electronic newspaper is continuously accessible all over the world, it could become an eye-catcher in discussing the issue of prejudiced news coverage of the immigrant population. Online journalism can put articles on the Internet which do not necessarily need to be published in print. This will stimulate more interactivity and therefore more involvement in collecting and presenting news.

Briefly, the media can play a crucial role in social-cultural integration and participation. However, we must distinguish between the general media and media with a specific content meant for distinct target audiences. It is this distinction which is dealt with in the present article.

\section{Previous reception research in the Netherlands}

Ethnicity issues have been very much in the foreground of public debate in the multicultural Netherlands in recent years, and in view of the pluriethnic character of Dutch society it can be assumed that they will attract even greater attention in the next few years. How has this public attention been reflected in research in the field of media use by ethnic minorities? A survey of research into ethnic minority groups and the media, with reference to the European Union and the Netherlands in particular, can be found in Racism and Cultural Diversity in the Mass Media, edited by Jessika ter Wal (2002).

An inventory compiled by Brants, Crone, and Leurdijk (1998) shows that relatively little research into the topic of minorities and media was carried out in the Netherlands until 1997. Many fields of study remained unexplored and, moreover, a good deal of the research undertaken turned out to be based on small-scale ad hoc samples, case-studies, and unpublished material, the scholarly quality of which often left much to be desired. A further striking feature of the research undertaken up to then was its largely quantitative nature. The Veldkamp market-research project long remained the only large-scale study in the Netherlands. It looked into the access to and the use of (new) media by ethnic minorities 
(1999, 1998, 1996), but the results do not go beyond the numerical description of ownership and use of media.

The inventory illustrates a slow change in the ethnic minorities' demand for information. In the early eighties, demand was mainly for information about the Netherlands and about other immigrants already living in the Netherlands, and for information which could facilitate living and functioning in the Netherlands. By the end of the decade there was also a demand for entertainment and news from the immigrants' country of origin. At the end of the nineties we find a dual-track demand: The average immigrant seeks information about his or her country of origin as well as social-economic and educational matters which could improve his of her functioning in the Netherlands.

Since 1997, more studies have become available and they are more varied too, both with regard to the methods used and to the types of media and ethnic groups studied. Yet we find that quantitative studies on the ownership and use of media types are mainly concerned with social-demographic features such as sex, age, schooling, and income as possible determinants of media ownership and use, and that culturespecific features are not discussed (see van Dijk et al., 2000). The studies conducted from a cultural-anthropological angle are mainly qualitative and do look at cultural-specific features such as identity, integration and cultural participation, but they rarely examine the use of media. Finally, media studies which examine social-demographic as well as culture-specific features in relation with media use are scarce and confine themselves to specific media types (e.g., ICT) and to particular groups of users (e. g., young people).

In 2003, native Dutch people continue to be significantly greater users of the Internet than ethnic minorities (d'Haenens, 2003). Also, they possess PCs, with or without an Internet facility, more frequently than ethnic minorities do (d'Haenens, 2003: 4). Of all ethnic minorities it is the Moroccan youngsters who are most prominent in public discussions on the Internet (Geense and Pels, 2002: 9). The computer in the library or at school plays a remedial role in bridging the digital divide, as is shown in, among others, a study of SCP (the social and cultural planning office), Van huis uit digitaal (Digital Homes) (de Haan et al., 2002). This study is based on a school survey of 1,213 pupils, among whom ethnic minority youngsters, who were asked about their computer skills and the role of ICT at school. Moroccan and Turkish pupils turned out to lag behind most, and to compensate for this they use the PC in the library and are the most frequent users of the school computers to look up information. The study also checked what the impact is of schooling and of the family situation on these differences. Apparently, the social background (i.e., characteristics of the parents and the availability of 
one or more PCs at home) offers the best explanation for the differences in digital skills.

The communication agency MCA Communicatie, for example, examined the reputation and the spread of multicultural daily newspapers and magazines in the four largest cities of the Netherlands (Amsterdam, The Hague, Rotterdam, and Utrecht) in March 2003. The sample consisted of 600 Moroccans, Turks and Surinamese. In June 2003, the same bureau examined, in the same cities, the reputation and the spread of Dutch newspapers in a sample of 644 Moroccans, Turks, and Surinamese of 15 years and older. In June 2002, MCA Communicatie had conducted faceto-face interviews about computer and Internet use among some 600 Turks, Moroccans, and Surinamese. The last-mentioned survey showed that Moroccans not only turn to websites with a Moroccan bias, but that $59 \%$ of them surf to predominantly Dutch websites too (MCA Communicatie, 2002). In May 2003, Foquz Etno-marketing, a bureau specialized in ethno-marketing, conducted street interviews with 180 Moroccan youngsters (between the ages of 15 and 19) about their use of radio and TV, the newspapers they read, and their preference for Moroccan websites.

Linders and Goossens (2004) confirm that Moroccan youngsters visit a wide range of websites. Girls tend to surf to websites of a predominantly Moroccan nature, doing so more often than boys. Clearly, also when surfing on the web, ethnic minority young people appear to drift between two cultures: They search for their ethnic-cultural identity while trying to join in with the society in which they live (De Waal, 2003). Another finding of the study of Linders and Goossens is that Internet and e-mail use contributes to bonding and bridging social capital and helps the social and political participation of ethnic minority youths. The study confines itself, though, to native and Moroccan Internet users in the Netherlands.

\section{School survey in the Netherlands and Flanders}

In a school survey carried out in the Netherlands and in Flanders among Turkish and Moroccan youngsters (in the Netherlands Surinamese youths were included as well) between the ages of 12 and 19, the construct 'ethnic-cultural position' as a criterion of integration was applied for the first time to media access and media use (d'Haenens et al., 2004; d'Haenens, Van Summeren, and Saeys, 2003; d'Haenens et al., 2002). Following Van Heelsum (1997: 24) 'ethnic-cultural position' was defined as 'the extent to which members of a given group look upon themselves primarily as members of a specific group and/or act as such (acquisition of position) and the extent to which (the bulk of) society considers them 
primarily as representatives of a specific group and/or treat them as such (allocation of position)'. The acquisition of position and the allocation of position are the two theoretical dimensions of the construct 'ethniccultural position'.

Acquisition of position was split up into three components. The first is connected with the question whether ethnic groups are distinguished, otherwise called group differentiation. Group differentiation is defined as "contrasting the image of the specific ethnic group concerned with that of other relevant ethnic groups, especially the dominant ethnic group(s) in society" (Van Heelsum, 1997: 61). This first component of ethnic-cultural position is in turn subdivided into three so-called observational terms as follows: 1) One's attitude towards Turks/Moroccans/ Surinamese, 2) one's attitude towards the native majority, and 3) the extent to which differences are perceived between Turks/Moroccans/Surinamese and the native majority.

The second component of the acquisition-of-position dimension can be paraphrased as ethnic self-definition and it is exemplified by the following statements: 1) I feel strong bonds with the Turkish/Moroccan/ Surinamese community and 2) I am totally different from my parents because I was born in the Netherlands/Flanders.

The third component includes, among others, questions about one's inclination to have contact with people in Turkey/Morocco/Surinam. Van Heelsum (1997: 66) defines this as "the extent to which, in one's social intercourse, one prefers, or one likes to turn explicitly to Turks/ Moroccans/Surinamese". This is illustrated by the two following statements: (1) I feel better at ease if there are Turks/Moroccans/Surinamese around; (2) I often feel left out by Dutch/Flemish people.

Following Van Heelsum (1997: 66), perceived allocation of position was defined as "the extent to which one's environment regards one as a member of a specific group (perception aspect) and the extent to which one is treated in a specific way (behavioral aspect)". The following are two illustrative statements: 1) As a Turk/Moroccan/Surinamese I feel fully accepted by my Dutch/Flemish schoolmates and 2) I feel discriminated against by other pupils at school. The key question addressed was: Are the attitudes of ethnic minority youngsters with regard to 'old' as well as 'new' media and their use of these media determined by culture-specific characteristics, in addition to other social-demographic features? The results of the study showed, amongst others, that ethnic-cultural position has a less substantial impact on young ethnic minorities' ownership and use of media than had initially been expected.

The school survey tried to distinguish between the perception one has of oneself in society and the perception others are believed to have of oneself. The combination of these components was linked to the distance 
perceived between the 'I' and the others and to the social contacts with native Dutch and Flemish people, producing a coherent measure of ethnic-cultural position based on 25 propositions (Cronbach's $\alpha$ of .82). It is a measure which is largely made up of the perception that individuals have of their position in society, but an individual's integration in society is obviously also related to concepts which he or she does not automatically link to his or her own ethnic-cultural background. The question then rises to what extent the norms and values one adheres to coincide with those of the 'majority'.

In brief, what Dutch research on media and ethnic minorities was still waiting for, was a study that not only looked into the media use of young ethnic minorities but also into that of older generations, and which, moreover, consistently distinguished between the use of the ethnic minorities' 'own' media as against Dutch-language media types. Such a study would thus examine the significance of these two groups of media for, on the one hand, the social-cultural integration of ethnic minority youngsters and their elders in Dutch society and, on the other, for maintaining relations within the respective groups of ethnic minorities. Also, information on the fourth large ethnic group in the Netherlands, from the Netherlands Antilles and Aruba, was badly needed.

The study 'Media and Ethnic Groups 2002'3 , a Dutch-language report produced public in 2004, largely fills this gap (Baardwijk et al., 2004) as it looks at both young and older minority audience groups and takes a systematic look at their Dutch-language media use as well as their use of the media in their 'own' language of the 'homeland'. The present article, drawing upon the data set of this study, emphasizes those variables which help to increase our understanding of the twofold function of the media: Bridging and bonding.

The question the present contribution addresses is the following: To what extent are, on the one hand, bonding (i.e., an immigrant's slant towards maintaining contact with the 'homeland') or, on the other, bridging (i. e., the desire to familiarize oneself with Dutch society and to participate in it socially and culturally) predictors of media use among ethnic minorities?

\section{Method}

The study involved Turks, Moroccans, Surinamese, Antilleans (including people from Aruba), and Chinese, all older than 13 and living in Amsterdam, Rotterdam, The Hague, Utrecht, Enschede, and Eindhoven. The term 'ethnic minority' was interpreted in a wide sense, the criteria for selecting respondents being native country or native country of (one of) the parents. 
Face-to-face interviews were conducted with people of 13 and older by interviewers who themselves belonged to the ethnic group they were interviewing. It was intended to have 400 interviews for each ethnic group, but in practice 408 Turks, 366 Moroccans, 388 Surinamese, 403 Antilleans, and 348 Chinese were interviewed. The present article confines itself to the first four groups as they are numerically the four largest ethnic-cultural minorities in the Netherlands.

The samples were weighted, on the one hand for sex, age, and native country (first against second generation) and, on the other, for schooling, using data concerning the nation-wide population of the ethnic groups in question as a reference point. The Turkish, Moroccan and Surinamese samples can be considered representative. The results for the Antillean group are to be regarded as tentative because the representation of generations in this group shows medium-class differences from population data. Even though the results were initially weighted for sex, age, and schooling, major differences remained in the Antillean group between the data from the sample and data concerning the population as a whole with regard to the share of first-generation respondents ${ }^{4}$.

The use of Dutch-language media as well as media in the immigrants' languages, both 'old' and 'new' (print media, radio and television, and ICT) was analyzed, focusing on the relation between use and appreciation on the one hand, and their impact on social-cultural participation and integration in Dutch society on the other. The ethnic minorities concerned belonged to four ethnic groups: Turks, Moroccans, Surinamese, and Antilleans.

In addition to social-demographic data (age, sex, native country, schooling, occupation, nationality, and composition of the family), the respondents were asked questions about their integration into Dutch society or about their orientation towards their country of origin; factors bearing on these questions are linguistic fluency (in Dutch and in the immigrants' own language or languages), contact with the native country, social intercourse with native Dutch people, religious convictions, and the immigrants' opinions about social issues. Other questions concerned the role of different types of media in obtaining news about the country of origin, the Netherlands, and the immigrants' own community. This includes the way immigrants use and appraise four media in their own language as opposed to Dutch-language media: Their pattern of listening to the radio and watching television, reading daily newspapers and magazines, and, finally, ICT applications. All these data are linked to the connection between social-cultural integration in Dutch society on the one hand and the use of media on the other.

Before going into the media-related results of the study, it is necessary to describe the concept of 'integration'. In doing so we look at the rela- 
tionship between those characteristics that bear on integration, on the one hand, and, on the other, the connection between integration and other background features (i.e., sex, age, schooling, social-economic status and the occupation of the chief breadwinner, native country, mother tongue, length of stay in the Netherlands, nationality, housing conditions, choice of partner, religious outlook). Four ethnic groups are compared, and two age categories distinguished: The group between 13 and 24, and older immigrants, who were not included in the school survey.

\section{Integration: Operationalization}

In all, 35 questions about integration were asked, relating to six dimensions: Command and use of the Dutch language, understanding of Dutch society, endorsement of the norms of Dutch society, social contacts with native Dutch people, Dutch identity, and motivation with respect to integration. After factor analyses it was deemed necessary to leave five questions out of consideration. The following lists only the questions which were effectively used:

1. Command and use of the Dutch language. The respondents were asked to indicate the level of their command of Dutch with regard to a) understanding, b) speaking, c) reading, and d) writing. They were also asked whether they had any language problems in slightly more official interviews or when reading subtitles, brochures, or newspaper articles. Finally they were asked how many days a week they speak Dutch.

2. Understanding of Dutch society. The respondents indicated whether and to what extent they were aware of 1) how Dutch people feel about a number of things in connection with daily life; 2) how the average Dutch person lives and works and what his house looks like; 3) how things go in Dutch schools, hospitals, municipal services and offices, and other institutions that citizens may come in contact with; 4) what Dutch laws and rules permit and do not permit, and 5) what goes on in national politics. These questions do not seek to make an accurate check of the effective knowledge that immigrants have of Dutch society; rather, they are designed to find out how the immigrants themselves experience their own problems.

3. Endorsement of norms prevalent in Dutch society. The extent to which the respondents of the four ethnic groups endorse the norms of Dutch society was determined by means of eight statements, five of which are the following: A woman should quit her job when she has a baby; It is better for elderly parents to live with their children than in an 
old people's home; In the Netherlands contact between men and women is too loose; In the Netherlands journalists have too much freedom to say and write as they wish; It is a pity that religion controls daily life in the Netherlands less and less. Clearly, utterances such as these are opposed to current dominant opinion in the Netherlands and fit in badly with a liberal, secularized and individualized society. For this reason we assume that the more our respondents reject these statements, the better they are integrated into Dutch society.

4. Social contact with native Dutch people. The intensity of the respondents' contact with Dutch people was checked by means of three questions, one of which was whether the interviewee occasionally visited Dutch people at their homes, and if so, how often.

5. Dutch identity. This dimension measures the extent to which the respondent feels a bond with the Netherlands. As a person can have several identities, the respondents were asked to determine the extent to which they felt Dutch as well as Turkish, etc. A further question was the extent to which the respondents thought they were regarded by others as Turkish, etc. Finally, they were asked to what extent they expected to remain in the Netherlands the rest of their lives.

6. Motivation with respect to integration. This dimension was dealt with in three questions: To what extent is the Netherlands a country where one can really feel at home? How important do respondents feel it is to know much about the Netherlands? How important do they feel it is to have contact with Dutch people?

After five questions that did not fit into the pattern had been left out, a scale was set up for each of the above-mentioned six dimensions of integration. Next, a general scale of integration was determined on the basis of these six scales. In the combined scale, the six dimensions carry the same weight thanks to standardization. Although this integration scale is fairly reliable (Cronbach's $\alpha$ of .73), it is still worthwhile to work with subscales as well ${ }^{5}$.

The Moroccan group is the only one in which motivation with respect to integration proves to correlate with the endorsement of 'Dutch' norms. Furthermore, the dimension regarding command and use of the Dutch language turns out to be of little significance in the case of the Surinamese respondents; after all, this group of immigrants have few problems with the Dutch language since Dutch is the official language of Surinam (Netherlands Guiana). Partly for this reason the reliability of the general scale of integration for the Surinamese group is considerably lower than for the other ethnic groups.

Table 1 shows the average score of each ethnic group for the six subscales and for the general scale of integration. On all the scales Moroccans 
Table 1. Integration and dimensions of integration: Averages per group. *

\begin{tabular}{|c|c|c|c|c|c|c|c|}
\hline & $\begin{array}{l}\text { Turks } \\
(\mathrm{n}=408)\end{array}$ & $\Leftrightarrow$ & $\begin{array}{l}\text { Moroccans } \\
(\mathrm{n}=366)\end{array}$ & $\Leftrightarrow$ & $\begin{array}{l}\text { Surinamese } \\
(\mathrm{n}=388)\end{array}$ & $\Leftrightarrow$ & $\begin{array}{l}\text { Antilleans } \\
(\mathrm{n}=403)\end{array}$ \\
\hline General integration & -.20 & $>$ & -.55 & $<$ & .34 & & .37 \\
\hline $\begin{array}{l}\text { 1. command/use Dutch } \\
\text { language }\end{array}$ & -.41 & & -.45 & $<$ & .48 & $>$ & .36 \\
\hline 2. knowledge Dutch society & -.10 & & -.18 & $<$ & .13 & & .13 \\
\hline 3. Dutch norms and values & -.37 & & -.51 & $<$ & .43 & & .42 \\
\hline $\begin{array}{l}\text { 4. social contacts with Dutch } \\
\text { people }\end{array}$ & -.18 & $>$ & -.44 & $<$ & .28 & & .30 \\
\hline 5. Dutch identity & .04 & $>$ & -.25 & $<$ & .07 & & .11 \\
\hline $\begin{array}{l}\text { 6. motivation with regard } \\
\text { to integration }\end{array}$ & .21 & $>$ & -.32 & & -.05 & $<$ & .11 \\
\hline
\end{tabular}

* Standardized scores. Significant differences marked with $<$ or $>$ (t-test, $\mathrm{p}<.05$, bilateral). The Mediterranean groups (Turks and Moroccans) were compared with the other groups (Surinamese and Antilleans). In addition, within the two main groups the two subgroups were compared with each other.

have a below-average score, especially with regard to their command and use of the Dutch language, their endorsement of 'Dutch' norms and values and the frequency of their contact with native Dutch people. The Surinamese have a high score on these three subscales, but a belowaverage score for their motivation with respect to integration. For the latter dimension it is the Turks who have the highest score.

All in all, the Surinamese and Antilleans prove to show the highest degree of integration and the Moroccans the lowest. A comparison of Turks with Moroccans reveals that Turks score significantly $(\mathrm{p}<.05)^{6}$ higher on the subscales of social contact with native Dutch people, Dutch identity, and motivation with respect to integration. If the Surinamese are compared with the Antilleans, the former have a better score for command and use of the Dutch language, and the latter for motivation with respect to integration. If, finally, the 'Mediterranean' group of Turks and Moroccans is compared with the 'Caribbean' group of the Surinamese and the Antilleans, the latter group has a higher score for all dimensions.

\section{Younger and older people}

In contrast with the school survey conducted in the Netherlands and Flanders, older people were included in the study as well. It is therefore worth looking into a comparison of the older group ( 25 and above) with the younger one (see Figure 1). Among the Turks and Moroccans the older people appear to be less integrated than the younger people. The differences in integration are more marked if we look specifically at the 


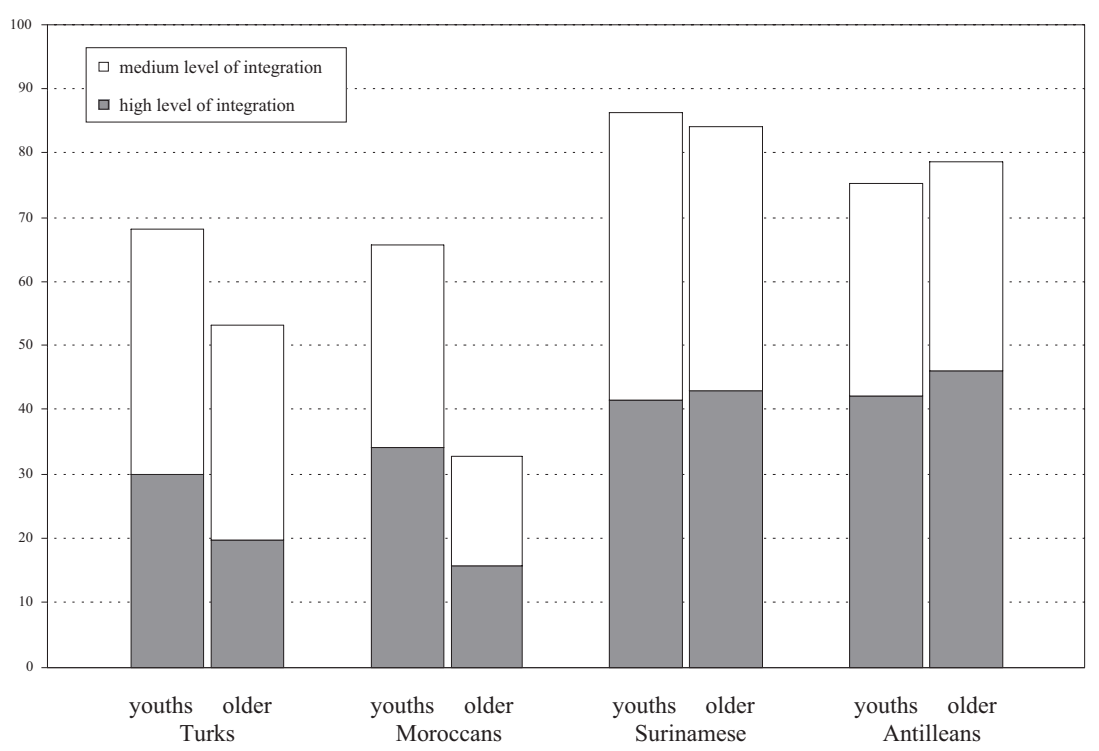

Figure 1. Twofold division of integration per age group (13-24 year-olds versus 25+): percentage with high or average level of integration.

respondents' command of the Dutch language. Among the Antilleans, unlike the Turks and Moroccans, it is the older group which is better integrated. Admittedly, the younger Antilleans have a better command of Dutch than their elders, but in most other respects (knowledge of Dutch society, social contacts with Dutch people, Dutch identity, and motivation with respect to integration) the older group is better integrated. Among the Surinamese the older group are integrated better with respect to their knowledge of Dutch society and their motivation with respect to integration, while the younger people have a better score for language and endorsement of 'Dutch norms and values'. Overall, among the Surinamese there is no significant difference between younger and older people.

\section{Other differences within the groups}

The level of integration does not depend on age alone; it is also linked to other social-demographic features such as sex and level of schooling ${ }^{7}$. Still, the differences between men and women are not substantial; the integration of Surinamese women is slightly better than of men (higher motivation with respect to integration), whereas the reverse is true of Antilleans (men have a higher score for knowledge of Dutch society and 
Table 2. Other background features.

\begin{tabular}{|c|c|c|c|c|c|}
\hline & & $\begin{array}{l}\text { Turks } \\
(\mathrm{n}=408)\end{array}$ & $\begin{array}{l}\text { Moroccans } \\
(\mathrm{n}=366)\end{array}$ & $\begin{array}{l}\text { Surinamese } \\
(\mathrm{n}=388)\end{array}$ & $\begin{array}{l}\text { Antilleans } \\
(\mathrm{n}=403)\end{array}$ \\
\hline \multirow{4}{*}{$\begin{array}{l}\text { How long } \\
\text { in the } \\
\text { Netherlands? }\end{array}$} & $\begin{array}{l}0-6 \text { years } \\
\text { in the Netherlands }\end{array}$ & 13 & 9 & 6 & 33 \\
\hline & $7-12$ years & 12 & 14 & 16 & 15 \\
\hline & 13 or more years & 52 & 54 & 51 & 32 \\
\hline & $\begin{array}{l}\text { born there (first } \\
\text { generation) }\end{array}$ & 23 & 23 & 27 & 21 \\
\hline \multirow{4}{*}{$\begin{array}{l}\text { At what age } \\
\text { in the } \\
\text { Netherlands? }\end{array}$} & $\begin{array}{l}\text { born there (first } \\
\text { generation) }\end{array}$ & 23 & 23 & 27 & 21 \\
\hline & $\begin{array}{l}\text { at the age of } 6 \text { or } \\
\text { younger }\end{array}$ & 9 & 17 & 10 & 7 \\
\hline & between 7 and 12 & 10 & 8 & 10 & 9 \\
\hline & at 13 or over & 57 & 53 & 53 & 64 \\
\hline \multirow{4}{*}{$\begin{array}{l}\text { Dutch as } \\
\text { mother tongue } \\
\text { (at age 6) }\end{array}$} & no Dutch & 68 & 72 & 8 & 45 \\
\hline & $\begin{array}{l}\text { Dutch as second } \\
\text { language }\end{array}$ & 30 & 25 & 25 & 31 \\
\hline & $\begin{array}{l}\text { Dutch as first } \\
\text { language }\end{array}$ & 2 & 3 & 42 & 10 \\
\hline & Dutch only & 1 & 0 & 25 & 14 \\
\hline \multirow[t]{3}{*}{$\begin{array}{l}\text { Importance } \\
\text { of religion }\end{array}$} & $\begin{array}{l}\text { Low (low score } \\
\text { on scale) }\end{array}$ & 23 & 12 & 49 & 53 \\
\hline & Medium & 32 & 50 & 32 & 23 \\
\hline & High & 45 & 38 & 19 & 24 \\
\hline \multirow[t]{3}{*}{$\begin{array}{l}\text { Housing } \\
\text { situation }\end{array}$} & $\begin{array}{l}\text { predominantly } \\
\text { immigrants }\end{array}$ & 58 & 58 & 50 & 45 \\
\hline & fifty-fifty mix & 24 & 28 & 27 & 31 \\
\hline & $\begin{array}{l}\text { predominantly } \\
\text { Dutch people }\end{array}$ & 17 & 15 & 23 & 24 \\
\hline
\end{tabular}

for identity). Schooling, by contrast, has an impact on nearly all forms of integration.

Table 2 lists other background differences which, in addition to integration, can have an influence on minorities' media use. They are features such as the age a person had when he or she arrived in the Netherlands (or - related to this - the number of years one has lived in the Netherlands) and the mother tongue, i. e., the language one spoke at age six: No Dutch at all, Dutch as a second language, Dutch as the first language next to another one, or Dutch as the only language. These three features determine an individual's starting point and are consequently closely related to his or her level of integration. Furthermore, there is the respondent's housing situation (i. e., living predominantly 
among native Dutch people or among ethnic minorities, or in a mixed neighborhood), which also influences the level of integration, though the relation is less strong. Finally, another important feature is the respondent's religious outlook, determined by how often he or she goes to a church or mosque to attend a religious meeting, and by the direct question to what extent religion or philosophical conviction plays a role in daily life.

On average Antilleans arrived later in the Netherlands than other groups. As far as language is concerned, Dutch is the mother tongue of the Surinamese more often than of the Antilleans, but it is the mother tongue of the latter much more often than of Turks and Moroccans. Religion is more important to Turks and (especially older) Moroccans than to the Surinamese and Antilleans. Those who claim that religion plays an important role in their daily lives turn out to be less well integrated. Finally, with regard to housing situation, Antilleans, in particular the older people, live in a 'white' district more often than Turks or Moroccans. Among the Moroccans the younger people live in a 'white' district more often than the older people.

\section{Results}

\section{Frequency of media use in general}

In the following we examine the frequency with which four media types are used by the four ethnic groups concerned. In doing so we distinguish between media use in general, to be discussed in the present section, and the selective use of the minorities' 'own' media or the share of the latter in the overall time spent on media, to be discussed in the next section. In each of the two cases we describe the differences between the four ethnic groups, subdividing them into a younger and an older group, and seek to find out to what extent the degree of integration in addition to other background features influences the minorities' use of media.

Listening to the radio. In contrast to native Dutch people ${ }^{8}$, of whom $92 \%$ occasionally listen to the radio, ethnic minorities rarely tune in to the radio (Table 3), Turks and Moroccans by far the least. Among those who never listen to the radio, the Antilleans outnumber the Surinamese. Among the Moroccans, those who never listen to the radio are primarily to be found in the older group. Age does not seem to make any difference in the three other groups, although older people who occasionally listen to the radio, do so for longer stretches of time. A finding which applies to all groups is that those whose integration level is higher, listen to the radio more often than those who are less integrated. This finding 
Table 3. Use of and time spent on four media by youngsters (13-24 year-olds) and older people $(25+)^{1}$.

\begin{tabular}{|c|c|c|c|c|c|c|c|}
\hline & & \multicolumn{3}{|c|}{ occasionally ( $\%)$} & \multicolumn{3}{|c|}{ average time (hours per week) ${ }^{2}$} \\
\hline & & all & youths & older & all & youths & older \\
\hline \multirow[t]{4}{*}{ Radio } & Turks & 39 & 41 & 38 & $4.7(12.1)$ & $3.5 \quad(8.5)$ & $5.2(13.9)$ \\
\hline & Moroccans & 37 & 46 & 32 & $3.9(10.6)$ & $4.3 \quad(9.3)$ & 3.7 (11.7) \\
\hline & Surinamese & 79 & 78 & 80 & $14.1(17.8)$ & 8.8 (11.3) & $16.1(20.3)$ \\
\hline & Antilleans & 70 & 75 & 67 & $10.5(15.1)$ & $9.5(12.6)$ & $11.1(16.5)$ \\
\hline \multirow[t]{4}{*}{ TV } & Turks & 97 & 96 & 97 & $19.3(20.3)$ & $14.7(16.0)$ & $21.5(22.4)$ \\
\hline & Moroccans & 92 & 92 & 93 & $16.0(17.5)$ & $14.0(15.3)$ & $17.0(18.5)$ \\
\hline & Surinamese & 98 & 100 & 96 & $18.7(19.6)$ & $17.6(17.9)$ & $19.1(20.3)$ \\
\hline & Antilleans & 98 & 98 & 99 & $22.3(22.9)$ & $22.0(22.1)$ & $22.5(23.3)$ \\
\hline \multirow[t]{4}{*}{ Print } & Turks & 63 & 59 & 66 & $(4.6)$ & $(3.1)$ & $3.4 \quad(5.2)$ \\
\hline & Moroccans & 40 & 57 & 30 & $(2.9)$ & $(3.1)$ & (2.6) \\
\hline & Surinamese & 88 & 90 & 87 & $(4.2)$ & $(2.9)$ & (4.7) \\
\hline & Antilleans & 90 & 92 & 89 & $3.3 \quad(3.7)$ & $2.3 \quad(2.5)$ & $3.8 \quad(4.3)$ \\
\hline \multirow[t]{4}{*}{ Internet } & Turks & 41 & 75 & 26 & (7.1) & $(7.8)$ & (6.2) \\
\hline & Moroccans & 37 & 71 & 18 & $(6.1)$ & $4.6 \quad(6.6)$ & $(4.8)$ \\
\hline & Surinamese & 64 & 89 & 55 & $5.3 \quad(8.3)$ & $9.8(11.0)$ & $3.5 \quad(6.4)$ \\
\hline & Antilleans & 70 & 92 & 60 & $7.6(10.8)$ & $10.5(11.5)$ & $6.2(10.3)$ \\
\hline
\end{tabular}

1 Number of youngsters: 125, 131, 109 and 133, respectively; number of older people: 274, 233, 277 and 270, respectively.

${ }_{2}$ Average time spent on each of the media by the complete group (in brackets the number of those using these media occasionally).

is not really due to the supposedly longer time they spend listening, but rather to the smaller number of respondents who never listen to the radio at all. It is only in the Moroccan group that those who are integrated better, actually listen for longer stretches of time, a habit which seems to be influenced mainly by social contacts with Dutch people.

Watching television. Most Turks, Moroccans, Surinamese, and Antilleans occasionally watch television (Table 3), though the present study found that there is a relatively high number of Moroccans who never watch television $(8 \%)$. We have no clear explanation for this phenomenon, which, as the table shows, affects average viewing time, Moroccans scoring lowest of all groups. In the Turkish and Moroccan groups, younger people (between the ages of 13 and 24) watch television less than older people, a finding which is true of the native Dutch population as well. In the groups of Surinamese and Antilleans the difference between the age groups is smaller and not significant. Except for the Surinamese, the lower the integration level, the more television is watched in general. 
Reading newspapers and magazines. Among those who occasionally read a paper or a magazine, Antilleans and Surinamese do so more often than Turks and especially Moroccans (Table 3). The term paper covers not only daily newspapers but, for example, also door-to-door papers. By way of comparison: $89 \%$ of Dutch people occasionally read a newspaper and $77 \%$ a magazine. In nearly all groups older people spend more time on newspapers and magazines than younger people, except for the Moroccans, of whom many older people never read papers or magazines at all. As far as popularity is concerned, the most widely read papers prove to be Spits and Metro, two free papers. Next are the largest national newspaper De Telegraaf, the free door-to-door newspapers, two more national newspapers, Algemeen Dagblad and De Volkskrant, and finally the regional newspapers. The higher the degree of integration, the more often ethnic minorities read newspapers and magazines. Moroccans find inadequate command of the Dutch language the major obstacle to reading newspapers. Antilleans find an important incentive for reading Dutch newspapers in their knowledge of Dutch society, while all the ethnic groups are prompted to read Dutch papers by their social contact with Dutch people.

Internet use and activities. Most Antilleans and Surinamese are occasional users of the Internet (Table 3), the former spending more time surfing on the web than the latter. Fewer than half of the Turks and Moroccans use the Internet. Great differences in the use of the Internet crop up when age is considered, particularly among the Moroccans. These differences are due to the fact that the older group often do not use the Internet at all; in the Surinamese group we find that the older people often surf for shorter stretches of time than the younger people. Generally speaking, Internet users go online at least once a week. In all ethnic groups the use of the Internet is related to the degree of integration, but even more to the age at which the respondents arrived in the Netherlands.

As the Internet offers a wide range of applications, it was thought necessary to have the respondents indicate how often they turned to each of the eight major Internet activities (Table 4). For all groups the most common activities on the Internet are the purposeful retrieval of information and e-mailing; the ethnic minority groups use it least often to order goods. By way of comparison: Chatting is much less popular among the native Dutch than among the ethnic groups under scrutiny. Likewise, downloading music files is relatively uncommon among Dutch people. In all groups those with a higher level of schooling go online more often to look for particular information and to use e-mail than those with a lower level of schooling. Youngsters in all groups use the Internet more often than the older group does for the purpose of chat- 
Table 4. Internet activities. *

\begin{tabular}{lllll}
\hline (n = Internet users) & $\begin{array}{l}\text { Turks } \\
(\mathrm{n}=153)\end{array}$ & $\begin{array}{l}\text { Moroccans } \\
(\mathrm{n}=113)\end{array}$ & $\begin{array}{l}\text { Surinamese } \\
(\mathrm{n}=233)\end{array}$ & $\begin{array}{l}\text { Antilleans } \\
(\mathrm{n}=280)\end{array}$ \\
\hline Random surfing & $75(25)$ & $76(23)$ & $77(23)$ & $69(22)$ \\
Retrieving information & $90(60)$ & $90(44)$ & $96(72)$ & $92(63)$ \\
E-mailing & $82(65)$ & $82(46)$ & $94(68)$ & $88(65)$ \\
Chatting & $64(34)$ & $63(28)$ & $60(31)$ & $58(37)$ \\
News groups & $38(6)$ & $37(9)$ & $30(9)$ & $36(13)$ \\
Downloading mp3 files & $59(29)$ & $45(20)$ & $55(32)$ & $63(42)$ \\
Other files & $61(25)$ & $49(18)$ & $58(18)$ & $60(29)$ \\
Ordering goods & $34(6)$ & $26(2)$ & $19(4)$ & $32(12)$ \\
\hline
\end{tabular}

* Percentage occasional use (sometimes or often); in brackets percentage frequent use.

ting, and, Moroccan and Antillean youths use it more often than older people for downloading music and other files. A final striking finding is that the more often Moroccans chat online the better their integration is, whereas the opposite is true of Turks and Antilleans: The better their integration, the less often they chat online.

\section{Bias towards ethnic minorities' 'own' media}

In the following we will discuss the extent to which ethnic minorities tend to favor their 'own' media, in other words, the share taken by these media in the overall time spent on the various media types. We will again try to find out what differences exist between younger and older people in the four ethnic groups concerned. Finally, we will also look into the relation between the degree of integration and media use.

Share of 'own' radio stations. All the groups listen to Dutch commercial radio stations most of the time. The programs of 747 AM, a public broadcasting channel, are meant for specific target groups and therefore attract only a small group of listeners, although some of them do occasionally tune into programs broadcasted by NMO (Muslim), OHM (Hindu), NPS (multicultural), and EO (evangelical). Table 5 shows what percentage of overall listening time is spent on stations that broadcast in the ethnic minorities' own languages, i.e., not to Dutch or foreign stations. The four groups spend less than one third of their listening time (even though it is already relatively limited, at least when compared with native Dutch people) listening to stations in their own language, the Surinamese most and the Antilleans least. This implies that they listen considerably more to Dutch stations than to stations from their various home countries; for all ethnic groups the share of other foreign stations 
Table 5. Share 'own' media supply in time spent by youngsters (13-24-year-olds) and older people (25+).

\begin{tabular}{|c|c|c|c|c|c|c|c|c|c|c|}
\hline \multirow{2}{*}{ Radio } & \multirow[b]{3}{*}{$\begin{array}{l}\text { Turks } \\
\text { Moroccans } \\
\text { Surinamese } \\
\text { Antilleans }\end{array}$} & \multicolumn{6}{|c|}{ share 'own' media } & \multicolumn{3}{|c|}{ relation to integration $(\mathrm{r})^{3}$} \\
\hline & & \multicolumn{2}{|c|}{$\begin{array}{l}\text { all } \\
\text { share (n) }\end{array}$} & \multicolumn{2}{|c|}{$\begin{array}{l}\text { youths } \\
\text { share (n) }\end{array}$} & \multicolumn{2}{|c|}{$\begin{array}{l}\text { older } \\
\text { share (n) }\end{array}$} & all & $\begin{array}{l}\text { youths } \\
-.44^{* *}\end{array}$ & $\begin{array}{l}\text { older } \\
\frac{-.41 * * *}{}\end{array}$ \\
\hline Radio & & $\begin{array}{l}28 \\
21 \\
29 \\
18\end{array}$ & $\begin{array}{l}158 \\
136 \\
308 \\
281\end{array}$ & $\begin{array}{l}27 \\
16 \\
18 \\
19\end{array}$ & $\begin{array}{r}52 \\
61 \\
85 \\
100\end{array}$ & $\begin{array}{l}29 \\
25 \\
33 \\
17\end{array}$ & $\begin{array}{r}103 \\
74 \\
220 \\
181\end{array}$ & $\begin{array}{l}-.41 * * * \\
-.30 * * \\
-.25 * * * \\
-.32 * * *\end{array}$ & $\begin{array}{l}-.44 * * \\
-.11 \\
-.18 \\
-.22\end{array}$ & $\begin{array}{l}-.41^{* * *} \\
-.37^{* *} \\
-.30^{* * *} \\
-.38^{* * *}\end{array}$ \\
\hline TV & $\begin{array}{l}\text { Turks } \\
\text { Moroccans }\end{array}$ & $\begin{array}{l}41 \\
31\end{array}$ & $\begin{array}{l}398 \\
338\end{array}$ & $\begin{array}{l}35 \\
15\end{array}$ & $\begin{array}{l}121 \\
121\end{array}$ & $\begin{array}{l}43 \\
41\end{array}$ & $\begin{array}{l}265 \\
215\end{array}$ & $\begin{array}{l}-.40 * * * \\
-.58 * * *\end{array}$ & $\begin{array}{l}-.46^{* * *} \\
-.43^{* * *}\end{array}$ & $\begin{array}{l}-.38^{* * *} \\
-.54^{* * *}\end{array}$ \\
\hline Print $^{1}$ & $\begin{array}{l}\text { Turks } \\
\text { Moroccans } \\
\text { Surinamese } \\
\text { Antilleans }\end{array}$ & $\begin{array}{r}52 \\
12 \\
7 \\
21\end{array}$ & $\begin{array}{l}256 \\
145 \\
340 \\
362\end{array}$ & $\begin{array}{r}38 \\
5 \\
3 \\
15\end{array}$ & $\begin{array}{r}74 \\
75 \\
98 \\
123\end{array}$ & $\begin{array}{r}58 \\
19 \\
8 \\
23\end{array}$ & $\begin{array}{r}180 \\
70 \\
241 \\
239\end{array}$ & $\begin{array}{l}-.48 * * * \\
-.34 * * * \\
-.13 * \\
-.31 * * *\end{array}$ & $\begin{array}{l}-.51 * * * \\
-.07 \\
-.19 \\
-.12\end{array}$ & $\begin{array}{l}-.44^{* * *} \\
-.44^{* * *} \\
-.13 \\
-.41^{* * *}\end{array}$ \\
\hline Internet $^{2}$ & $\begin{array}{l}\text { Turks } \\
\text { Moroccans } \\
\text { Surinamese } \\
\text { Antilleans }\end{array}$ & $\begin{array}{l}54 \\
41 \\
46 \\
49\end{array}$ & $\begin{array}{l}153 \\
113 \\
233 \\
280\end{array}$ & $\begin{array}{l}52 \\
43 \\
42 \\
50\end{array}$ & $\begin{array}{r}94 \\
92 \\
96 \\
122\end{array}$ & $\begin{array}{l}55 \\
34 \\
49 \\
49\end{array}$ & $\begin{array}{r}72 \\
41 \\
151 \\
162\end{array}$ & $\begin{array}{l}-.47 * * * \\
-.26 * \\
-.31 * \\
-.53 * * *\end{array}$ & $\begin{array}{l}-.54 * * * \\
-.33 * \\
-.48 * * * \\
-.43 * * *\end{array}$ & $\begin{array}{l}-.41^{* *} \\
-.03 \\
-.21^{*} \\
-.61^{* * *}\end{array}$ \\
\hline
\end{tabular}

\footnotetext{
${ }^{1}$ For the print media the total number bears on Dutch 'own' papers and magazines. No questions were asked about foreign papers and magazines.

2 Index $(0-100)$, measuring the importance of the country of origin and the immigrants' own community in the Netherlands as far as communication by way of the Internet and online information retrieval are concerned (Table 7).

${ }^{3}$ Correlation coefficient of the share of 'own' media - general integration scale: $* * * \mathrm{p}<.001, * * \mathrm{p}<.01,{ }^{*} \mathrm{p}<.05$ (bilaterally tested).
}

is between 6 and $10 \%$, for younger as well as for older people. The share of stations in their own language is highest for the Surinamese $(29 \%)$ and lowest for the Antilleans (18\%). In the Surinamese group we find that older people listen relatively often to stations from their country of origin.

In all the ethnic groups examined, we find that those who often listen to stations from their country of origin are often less well integrated. They prove to have come to the Netherlands at a later age, to have enjoyed a low level of schooling, and to have strong religious convictions. The relation with religious outlook is especially marked in the group of Moroccans. The relation between the degree of integration and the share of listening time taken by stations from the country of origin is strongest in the Turkish group $(\mathrm{r}=-.41)$ and least strong in the Surinamese group $(\mathrm{r}=-.25)$. In all this, it is not only the dimension of command and use of the Dutch language that is important, but also that of social contact with Dutch people. 
Share of ethnic minorities' 'own' television stations. Thanks to dish antennas, viewers in the Netherlands can receive about eleven Turkish television channels, two Moroccan public channels (RTM1, Radio-Télévision Marocaine, broadcasting in Arabic and in three Berber languages, and RTM2, broadcasting in French), and finally some ten Arabic-language channels. At the time the present data were collected, there were no Surinamese or Antillean channels that could be received in the Netherlands. However, the situation changed in January 2003 when A-TiVi was started up, an Antillean-Aruban channel which broadcasts mainly in Papiamentu; moreover, in March 2003 TeVe-Sur was set up, which is intended for the Surinamese living in the Netherlands and which broadcasts a selection of programs already aired in Surinam. The Turks' favorite TV channels are those from their country of origin; the Moroccans favor RTL4, followed by Moroccan channels. Among the Surinamese and Antilleans SBS6 is the most popular channel. The Dutch public broadcasters are not among the five favorite channels, except among Moroccans (N1 and N2) and Surinamese (N1). For all the groups N3 ranks seventh or eighth. NMO programs are watched most by (mainly older) Turks and Moroccans; OHM is watched most by Surinamese (and again mainly by older people).

The most popular among the Turkish-language channels is the Turkish public channel TRT International, which can often be received via the cable; it is the channel they watch most frequently, and they prefer $(35 \%)$ it to other Turkish channels. The Turkish Kanal D and Show TV, both of which are commercial channels, also enjoy great popularity, followed by ATV and Star TV. Moroccans living in the Netherlands favor the Moroccan public broadcaster RTM1 best and actually often prefer $(65 \%)$ this channel to the other Arabic channels that can be received in the Netherlands via dish antennas or the cable. RTM1 is followed by the news channel Al Jazeera and, at some distance, the English/Arabic channel MBC is ranked third.

Table 5 presents a comparison between watching Dutch channels and 'homeland' channels. The lower the integration level, the more time is spent in front of the 'own' programs in the 'own' language by, in particular, the Turks and the Moroccans, the Surinamese and Antillians not having any 'own' programs to watch at the time of the data collection. In all, Turks as well as Moroccans appear to watch Dutch channels more frequently than channels from Turkey or Morocco, and this applies most of all to young Moroccans. The same correlation that we found for radio listeners crops up here: Turks and Moroccans who often watch channels from Turkey or Morocco also prove to have a low level of schooling, to have come to the Netherlands at a later age, to have strong religious convictions, and to not be well integrated. In the Moroccan group we find that the share of Moroccan channels in the time spent watching 
television is not only closely related to integration $(\mathrm{r}=-.58)$ but also to age $(\mathrm{r}=.54)$. To a somewhat lesser extent this is also true of Turks $(\mathrm{r}=-.40$ and $\mathrm{r}=.24$, respectively). As far as the older group of Moroccans is concerned, it is striking that social contact with Dutch people and speaking Dutch at home does not necessarily form an obstacle to watching Moroccan channels.

Share of ethnic minorities' 'own' newspapers and magazines. Table 5 also shows the percentage of reading time taken by newspapers and magazines in the respondent's language; reading time here does not include time spent reading newspapers and magazines from other countries than the Netherlands and the immigrant's country of origin, since no questions were asked about this. For Turks the time spent on reading newspapers and magazines in Turkish and on their Dutch equivalents is about equal. Surinamese (93\%), Moroccans (88\%), and Antilleans (79\%) usually read Dutch papers and magazines. The table also makes it clear that the older group of immigrants read their 'own' newspapers and magazines more often than younger people do (the difference is not significant in the case of the Antilleans). In the Surinamese group the correlation between reading their 'own' papers and magazines and the degree of integration is less marked $(\mathrm{r}=-.13)$ than for the Turks $(\mathrm{r}=-.48)$, Moroccans $(\mathrm{r}=-.34)$, and Antilleans $(\mathrm{r}=-.31)$.

Media online and communication via the Internet: The Netherlands versus country of origin. Table 6 indicates how often the respondents go online for radio, television, newspapers, and magazines and how often the Internet is used to have contact with others. The table registers the percentages of those who do so occasionally (often or sometimes) and in brackets those who do so often.

Unlike radio, television, and print media, for the Internet one cannot determine the percentage of time taken up by input from the immigrants' 'own' community or from their country of origin. Still, we did calculate an index that measures the extent to which online communication and consulting media online are slanted towards the country of origin and the respondent's own group. The average scores for this index are given in Table 7. The Internet is often used by all ethnic groups to make contact in their country of origin as well as with their own community in the Netherlands, most of all by the Turkish group and least by the Moroccans. In this respect there is no significant difference between younger and older people in any of the groups. The extent to which communication via the World Wide Web and consultation of online media are slanted towards the country of origin and the respondent's own community is related to integration in all the ethnic groups. The relation is 
Table 6. Media online and communication via the Internet.*

\begin{tabular}{|c|c|c|c|c|}
\hline$(\mathrm{n}=$ Internet users) & $\begin{array}{l}\text { Turks } \\
(\mathrm{n}=153)\end{array}$ & $\begin{array}{l}\text { Moroccans } \\
(\mathrm{n}=113)\end{array}$ & $\begin{array}{l}\text { Surinamese } \\
(\mathrm{n}=233)\end{array}$ & $\begin{array}{l}\text { Antilleans } \\
(\mathrm{n}=280)\end{array}$ \\
\hline Reading Dutch papers or magazines & (6) & (4) & $29(10)$ & $29(11)$ \\
\hline Reading 'own' papers or magazines & (6) & (1) & $22 \quad(5)$ & $34(13)$ \\
\hline $\begin{array}{l}\text { Listening to programs on Dutch } \\
\text { radio stations }\end{array}$ & (2) & (1) & $17 \quad(5)$ & $15 \quad(4)$ \\
\hline Listening to 'own' radio stations & (3) & (1) & $19 \quad(3)$ & (8) \\
\hline $\begin{array}{l}\text { Watching TV or video programs } \\
\text { of Dutch channels }\end{array}$ & $13 \quad(4)$ & (4) & $22(10)$ & $20 \quad(7)$ \\
\hline $\begin{array}{l}\text { Watching TV or video programs of } \\
\text { 'own' channels }\end{array}$ & (6) & (3) & $20 \quad(5)$ & $22 \quad(7)$ \\
\hline $\begin{array}{l}\text { Contact with their own community } \\
\text { in the Netherlands }\end{array}$ & $23(10)$ & (8) & $41(20)$ & $47(24)$ \\
\hline $\begin{array}{l}\text { Contact with people from the } \\
\text { country of origin }\end{array}$ & $25 \quad(9)$ & (3) & $35(14)$ & $46(27)$ \\
\hline Contact with native Dutch people & (9) & (5) & $43(20)$ & $52(29)$ \\
\hline $\begin{array}{l}\text { Contact with other foreigners in } \\
\text { the Netherlands }\end{array}$ & (8) & (5) & 41 (17) & $45(18)$ \\
\hline
\end{tabular}

* Percentage occasional use (sometimes or often); in brackets percentage frequent use. From the results an index $(0-100)$ was derived, indicating the extent to which the country of origin and the immigrants' own community in the Netherlands dominate in online media use and in Internet communication; the activities printed in italics are set off against the sum of all activities. The results are to be found in Table 7 .

strongest for the Antillean group $(\mathrm{r}=-.53)$ and the Turks $(\mathrm{r}=-.47)$ and less strong for the Surinamese $(\mathrm{r}=-.31)$ and Moroccans $(\mathrm{r}=-.26)$. The most influential element appears to be the extent to which the respondent feels he or she can identify with the Dutch.

\section{Media menu: The integrated approach}

Table 7 lists the average amount of time that each ethnic group spends on six media: Apart from radio, television, print media, and the Internet, we also include CDs or other sound carriers, and DVDs or videotapes. The amount of time is based on estimates made by the respondents themselves.

Spending 61 and 59 hours per week, respectively, on media, Antilleans and Surinamese are undeniably heavy users. In the life of the Turkish and Moroccan groups, by contrast, the media prove to take a less prominent place, with 41 and 32 hours per week, respectively. However, it should be noted that some media (notably books) were not included in the study; also, media can be used in combination with other media 
Table 7. Amount of time spent on media in hours per week.*

\begin{tabular}{|c|c|c|c|c|}
\hline & $\begin{array}{l}\text { Turks } \\
(\mathrm{n}=408)\end{array}$ & $\begin{array}{l}\text { Moroccans } \\
(\mathrm{n}=366)\end{array}$ & $\begin{array}{l}\text { Surinamese } \\
(\mathrm{n}=388)\end{array}$ & $\begin{array}{l}\text { Antilleans } \\
(\mathrm{n}=403)\end{array}$ \\
\hline Radio & $4.7 \quad(8)$ & $3.9 \quad(10)$ & $14.1 \quad(21)$ & $10.5 \quad(15)$ \\
\hline $\begin{array}{l}\text { CD and other sound } \\
\text { carriers }\end{array}$ & $8.3 \quad$ (19) & $5.8 \quad(17)$ & $11.6 \quad(20)$ & $12.8 \quad(21)$ \\
\hline Television & $19.3 \quad(51)$ & $16.0 \quad(55)$ & $18.7 \quad(34)$ & $22.3 \quad(39)$ \\
\hline DVD and video & $3.2 \quad(7)$ & (8) & $5.8 \quad(10)$ & $4.1 \quad(7)$ \\
\hline $\begin{array}{l}\text { Newspapers and } \\
\text { magazines }\end{array}$ & $2.9 \quad(8)$ & (5) & $3.6 \quad(7)$ & $3.3 \quad(7)$ \\
\hline Internet & $2.9 \quad(7)$ & $2.2 \quad(5)$ & $5.3 \quad(8)$ & $7.6 \quad(11)$ \\
\hline Total media time & $41.3(100)$ & $31.7(100)$ & $59.2(100)$ & $60.7(100)$ \\
\hline
\end{tabular}

\footnotetext{
* In brackets: percentage of total media time (average of all respondents' percentages).
}

(especially young people often engage in multitasking). Consequently the concept of 'total media time' should be used with some caution. Nevertheless, for each of the four ethnic groups Table 7 lists the shares of the various media in the total media time.

In all groups television is the first and foremost medium. Moroccans $(55 \%)$ and Turks $(51 \%)$ spend more than half of their total media time watching television; that share drops to $39 \%$ for Antilleans and to $34 \%$ for Surinamese. In the Moroccan, Turkish and Antillean groups people with a low schooling level and a low degree of integration watch more television than those with a high schooling level. Among Turks and Moroccans women watch television more often than men. Among Moroccans, Surinamese, and Antilleans video tapes and DVDs are more popular with the younger than with the older group. Surinamese respondents spend a larger percentage of their total media time to listening to the radio than other groups $(21 \%)$. A striking feature of the Moroccan group is that those respondents with a high level of schooling and a higher degree of integration listen to the radio relatively often; it follows that Moroccan youngsters listen to the radio more often than older respondents in that group. As a matter of fact, other audio media are, generally speaking, also very popular among young people. The time spent reading newspapers and magazines is not higher than $8 \%$ of the total media time in any of the groups, though in all groups it is the older respondents who tend to read more than the youngsters. Respondents who frequently read papers and magazines are often also better integrated. Antilleans (11\%) spend relatively much of their media time on the Internet. Among Turks and Moroccans it is mainly those with a higher level of schooling who go online more often. Moroccan men use 
Table. 8. Threefold division per ethnic group. *

\begin{tabular}{llllll}
\hline & & $\begin{array}{l}\text { Turks } \\
(\mathrm{n}=408)\end{array}$ & $\begin{array}{l}\text { Moroccans } \\
(\mathrm{n}=366)\end{array}$ & $\begin{array}{l}\text { Surinamese } \\
(\mathrm{n}=388)\end{array}$ & $\begin{array}{l}\text { Antilleans } \\
(\mathrm{n}=403)\end{array}$ \\
\hline All & Homelanders & 55 & 28 & 19 & 29 \\
& Omnivores & 28 & 27 & 43 & 37 \\
& Adapters & 17 & 45 & 38 & 34 \\
\multirow{5}{*}{ Young } & Homelanders & 39 & 6 & 7 & 27 \\
& Omnivores & 36 & 32 & 49 & 43 \\
& Adapters & 25 & 62 & 44 & 30 \\
\multirow{5}{*}{ Older } & Homelanders & 62 & 41 & 24 & 30 \\
& Omnivores & 25 & 24 & 41 & 34 \\
& Adapters & 13 & 35 & 35 & 36 \\
\hline
\end{tabular}

* The score for the share of the 'own' media supply is being standardized per medium type; after that the means is calculated on the basis of the use of the four media types (where applicable).

Table 9. Link between level of integration etc. and orientation to the 'homeland' as seen in the media menu.

\begin{tabular}{|c|c|c|c|c|}
\hline Multiple regression (Beta) & $\begin{array}{l}\text { Turks } \\
(\mathrm{n}=408)\end{array}$ & $\begin{array}{l}\text { Moroccans } \\
(\mathrm{n}=366)\end{array}$ & $\begin{array}{l}\text { Surinamese } \\
(\mathrm{n}=388)\end{array}$ & $\begin{array}{l}\text { Antilleans } \\
(\mathrm{n}=403)\end{array}$ \\
\hline Age & $.16^{*}$ & $.16^{*}$ & $.24 * * *$ & .13 \\
\hline Gender $(1=\mathrm{M} 2=\mathrm{F})$ & $.18^{* * *}$ & .05 & .06 & .03 \\
\hline Level of schooling & -.06 & -.06 & -.04 & -.04 \\
\hline Level of integration & $-.41 * * *$ & $-.36 * * *$ & $-.23 * * *$ & $-.37 * * *$ \\
\hline $\begin{array}{l}\text { Time in the Nederlands } \\
\text { (4 levels }- \text { see Table } 2)\end{array}$ & .04 & .13 & .03 & .07 \\
\hline $\begin{array}{l}\text { Dutch as mother tongue } \\
(4 \text { levels }- \text { see Table } 2)\end{array}$ & -.04 & .01 & -.06 & -.04 \\
\hline Importance of religion & .07 & $.11 *$ & .08 & .07 \\
\hline $\begin{array}{l}\text { Housing situation } \\
\text { (3 levels - see Table } 2)\end{array}$ & .05 & .02 & $-.11^{*}$ & -.02 \\
\hline R (Adjusted R square) & $.59(.33)$ & $.61(.36)$ & $.45(.18)$ & $.50(.23)$ \\
\hline
\end{tabular}

the Internet more often than women do. In the Surinamese and Antillean groups youngsters go online more often than respondents in the older group.

Looking at the ratio between Dutch media use as opposed to the 'own' media use, the ethnic groups can be categorized in three distinct groups: 1) Homelanders, who predominantly use their 'own' media; 2) omnivores, who use their 'own' media more or less just as much as the Dutch media, and 3) adapters, who predominantly use Dutch-language media. The Turks, especially the older group, predominantly turn to their 'own' media, as opposed to the young Moroccans who are predominantly adapt- 
ers, even to a greater extent than the Surinamese and Antillians who mostly combine their 'own' media with the Dutch-language media.

By means of multiple regression analysis (Table 9) we checked the extent to which the relation between integration and media use can be explained by differences in other background features (age, schooling, the age at which the respondents arrived in the Netherlands, whether their mother tongue was Dutch, their religious outlook, and their housing situation). The degree of integration proves to be the most powerful predictor of the percentage of time that respondents spend on media from their country of origin or in their own language.

\section{Conclusions and discussion}

We have sought to depict ethnic minorities' dual-track media use and to find out which media are best suited to meet the users' wishes, both of younger and older ethnic minorities. In doing so we have also checked whether trends in the use of media continue their course or if, depending on the age group to which one belongs, they are reversed.

One conclusion is that the integration of young people is better than that of their elders, at least among Turks and Moroccans, a finding that points to an evolution in the process of integration. This does not apply, however, to minorities of Surinamese and Antillean descent. Besides, the integration of the two latter groups is, in every respect, further advanced, and the historical ties that the two groups have with the Netherlands are of a different kind, too. It looks as if the advance of integration has stopped in the Surinamese and Antillean groups and they have reached a point where bridging and bonding are balanced. It could also mean that in these two groups the process of integration is merely slowing down.

Judging from minorities' media use and the types of media used, it looks as if there is a positive correlation between integration and general media use. This finding is also borne out by the difference between, on the one hand, selective media use among the less well integrated Turks and Moroccans and, on the other, extensive media use among the highly integrated Antilleans and Surinamese. This is certainly true where reading newspapers and magazines and listening to the radio are concerned. Watching television, however, has a negative correlation with integration, and this applies to all the ethnic minority groups studied: The less successful integration is, the larger the amount of time spent watching television, in particular programs with a 'homeland' slant, except for the Antilleans and Surinamese, who, in the Netherlands, have no access to television programs from their own country of origin. As far as the Internet is concerned we find a correlation between integration and owngroup bias for all groups; in the Surinamese group we notice that less 
well integrated individuals use the Internet more often, thus making up for the lack of 'homeland' television programs, which Moroccans and Turks can watch via satellite dish. Youngsters who are more integrated can therefore be expected to use general media more often than their elders, except for the Internet (where the generation gap plays a role); the older group cannot resort to the potential for bonding offered by the Internet.

Still, if integration is closely connected with a more general media use, this need not necessarily be at the expense of the use of 'homeland' media, by means of which immigrants can keep in contact with their own cultural background. To be sure, well integrated immigrants turn to Dutch media more often, but it should not be forgotten that they use more media time overall, so that ultimately they do not spend less time on media from their own culture. A good example is that of television: The lower television use by highly integrated Turks and Moroccans does not exclude relatively high exposure to programs with a 'homeland' slant. There is therefore no clash between bridging and bonding. As a matter of fact, in practice integration does not entail the loss of one's own cultural identity but rather a deeper involvement in the other culture. In this way bridging and bonding go hand in hand. This is best exemplified in the use of the Internet, but it is true of all the media types examined, except for television, since watching programs with a homeland slant is done at the expense of Dutch-language programs. A low degree of integration, after all, is no obstacle to watching television.

The school survey conducted among Turkish, Moroccan, and Surinamese youngsters produced very similar trends. These younger generations emerge as information seekers with a wide-ranging interest, who, in order to stay abreast of developments in Dutch society, successively turn to television, newspapers, and the radio as the most appropriate news channel. Three quarters of Turkish and Moroccan youngsters also state that their major source of information about their 'homeland' is television programs from Turkey or Morocco. Moreover, Turks mention Turkish television programs as their best information channel more often than Moroccans do. The interest that minority youths show in events in Turkish or Moroccan society is almost as great as their interest in the Netherlands. Moroccans in particular often have little access to print media from their 'homeland' and consequently read more Dutch newspapers, whereas Turks tend to read more Turkish newspapers, which is not surprising in view of the greater variety of Turkish media available in the Dutch market and the poor command that Moroccans have of written Arabic.

Although Internet discussion groups for Moroccan youngsters living in the Netherlands are quite popular (www.maroc.nl and www.maghreb.nl), it is striking that Moroccan youths, generally speaking, resort to the PC 
less than their Turkish, Surinamese, and Dutch peers. Still, all the minority groups examined visit chat rooms very often; they often make well considered use of ICT applications, actively participating in news groups, looking for information about religion, art, and culture, and keeping abreast of developments in their country of origin. Depending on the strength of their religious convictions, they resort to the Internet as a guide in the maze of norms and values, exchanging views with each other, and especially with like-minded peers, about norms and values, the interpretation of Islam in the West, etc.

A 'Follow-up study of the school survey' (d'Haenens et al., 2004), dealing with Turkish and Moroccan youngsters only, seeks to find out if media use is slanted towards cross-ethnic segregation (i.e., bonding) rather than exchanges between ethnic groups and the furthering of participation of ethnic minorities in Dutch society (i. e., bridging). The results point to different patterns in preferences for Dutch-language or 'homeland'-biased media. When comparing the data for Dutch-language radio and television and for 'homeland' radio and television channels, Turkish youngsters predominantly turn to their Turkish channels, whereas their Moroccan peers prefer Dutch-language programs. The former group can therefore more often be classified as 'homelanders' and the latter as 'adapters', a finding which is borne out by the present study. Turkish youths read about as many Turkish as Dutch newspapers; by contrast, Moroccan youths predominantly read Dutch newspapers. With regard to reading magazines, most ethnic minority youngsters are adapters, with a preference for Dutch-language magazines. In this respect Turkish youngsters tend to use a combination of Turkish and Dutch periodicals. Turkish young people with strong sympathies for their country of origin surf on the Internet in order to find news about Turkey more often than about the Netherlands, and can therefore again be classified as 'homelanders', in contrast with those who tend to look away from Turkey and more often tend to surf the Internet in order to learn about Dutch society.

Putting it in a nutshell: There may admittedly be differences in the media menu, with preferences for either Dutch-language or 'homeland' media, but integration need not necessarily imply a rupture. On the contrary, it creates a new tie. Hence, there is no reason, or at least hardly any, for the older generations of ethnic minorities or for 'conservative' immigrants to be wary of the process of integration. 


\section{Notes}

1. Information on the current situation can be found at: www.cbs.nl/nl/cijfers/kerncijfers/mensmaatschappij.htm\#Bevolking.

2. This concessionary policy plan for 2000-2010 can be found at: http://www. omroep.nl/cbp.

3. In $2002 \mathrm{KLO}$, the audience research department of NOS, the Public Broadcasting Service, carried out research into the media use of ethnic minorities; the study was ordered by the above-mentioned NPS, the public broadcasting organization itself, and the department Public and Communication of RVD (the national information agency).

4. Professor J. J. C. M. Hox, of the capacity group Methodology and Statistics of the Utrecht University, has compared the data from the survey with the data of CBS, the Dutch Census Bureau. For each population group he has determined a measure indicating the deviation of the survey data from the CBS data. The measure is $\mathrm{W}$ and is presented by Jacob Cohen in his Power Analysis (Cohen, 1988). The standard, as presented by Cohen, is that a $\mathrm{W}$ of .1 is said to be small, a $\mathrm{W}$ of .3 is medium large, and a $\mathrm{W}$ of .5 is large. For the comparison between survey data and CBS data this produces the following result: Turks .04, Moroccans .13, Surinamese .05 , and Antilleans .25. In terms of Cohen's standard, the difference for the Turkish, Moroccan, and Surinamese groups is small and therefore acceptable; for the Antilleans it is medium large. In view of the quality of the CBS data, they can be considered to be a 'golden standard', and consequently a medium-large difference is not acceptable. As a result the data of the Antillean group are to be regarded as tentative.

5. For each dimension the degree of integration was determined by splitting the scores of individual items, if necessary after pole reversal (i. e., when a low score refers to a high degree of integration). The scores were first standardized to make sure that all items (irrespective of the extent to which they diverge, and therefore irrespective of the range of the scale) are given the same weight and that missing scores do not entail any problems. Next the result of the splitting was in turn standardized in order to facilitate the comparison of the six integration scales. Cronbach's $\alpha$ for command and use of the Dutch language (7 items) is .97, for knowledge of Dutch society (5 items) .87, for endorsement of Dutch norms (8 items) .70, for social contacts with Dutch people (3 items) .82, for Dutch identity (4 items) .69 , and for motivation with respect to integration (3 items) .61. Cronbach's $\alpha$ of .73 for the combined scale of integration is certainly acceptable, though it is not particularly high. Still, the scale contains diverging dimensions of integration, so that it can be assumed to present a well balanced view of the effect of various degrees of integration on media use.

6. Cronbach's $\alpha$ of .47 for the Surinamese group, as opposed to values ranging from .70 to .82 for the other groups.

7. Weighting has been applied on the basis of the features sex, age, native country (first as opposed second generation), and schooling. Market researchers routinely use weighting; however, in testing differences between groups they rarely allow for the effects on the reliability of their results. The present study does make allowance for these effects. By means of a corrective factor we estimated how much smaller than the observed sample the effective one is. The corrective factor was calculated by dividing $\mathrm{N}$ by the sum of squared weights (which on average are 1).

8. For the sake of comparison, at the same time when the study was conducted among ethnic groups a random sample of the Dutch population above 13 years was questioned by phone. They were asked a number of the questions that were also asked 
the ethnic minorities. Next, ethnic minority respondents were removed from the random sample in order to be able to compare the five ethnic groups with native Dutch people $(\mathrm{n}=550)$. Reference data that concerned reading newspapers and magazines were collected in another phone survey (Leefstijlenpanel Publieke Omroep 2002 - lifestyle panel of the public broadcasting organization).

\section{References}

Baardwijk, C., Dragt, E., Peeters, A., and Vierkant, P. (2004). Mediagebruik etnische publieksgroepen 2002 [Media Use Ethnic audience Groups 2002]. Hilversum: Public Service Broadcasting.

Brants, K., Crone, L., and Leurdijk, A. (1998). Media en migranten. Inventarisatie van onderzoek in Nederland [Media and Migrants. Inventory of Research in the Netherlands]. Amsterdam: University of Amsterdam.

Castells, M. (1997). The Power of Identity. Malden, MA: Blackwell.

Cohen, J. (1988). Statistical Power Analysis for the Behavioral Sciences (2 ${ }^{\text {nd }}$ ed.). Mahwah, NJ: Lawrence Erlbaum.

Dijk, J. van (2003). De digitale kloof wordt dieper. Van ongelijkheid in bezit naar ongelijkheid in vaardigheden en gebruik van ICT [The digital divide becomes wider. From unequal ownership to inequity in ICT use and skills]. The Hague: SQM.

Dijk, L. van, Haan, J. de, Rijcken, S, Verweij, A., and Ganzeboom, H. (2000). Moderne informatie- en communicatietechnologie en sociale ongelijkheid [Modern information and communication technologies and social inequality]. The Hague: Social and Cultural Planning Office of the Netherlands.

Geense, P. and Pels, T. (2002). Allochtone jongeren op het internet [Ethnic minority youths on the Internet]. Migrantenstudies, 18(1), 2-18.

Haan, J. de, Huysmans, F., and Steyaert, J. (2002). Van huis uit digitaal. Verwerving van digitale vaardigheden tussen thuismilieu en school [Digital homes. Acquisition of digital skills between the home and school contexts]. The Hague: Social and Cultural Planning Office of the Netherlands.

d'Haenens, L., Summeren, C. Van, Saeys, F., and Koeman, J. (2004). Integratie of identiteit? Mediamenu's van Turkse en Marokkaanse jongeren [Integration or Identity? Media menus of Turkish and Moroccan youth]. Amsterdam: Boom.

d'Haenens, L. (2003). ICT in multicultural society. The Netherlands: A context for sound multiform media policy? Gazette: The International Journal for Communication Studies, 65(4-5), 401-421.

d'Haenens, L., Summeren, C. van, and Saeys, F. (2003). Marokkaanse en Turkse jongeren in Nederland en Vlaanderen gaan digitaal. De rol van de etnisch-culturele positie bij de toegang tot en het gebruik van ICT [Moroccan and Turkish youngsters go digital. The role of ethnic-cultural position in terms of access to and use of ICT]. Migrantenstudies, 4, 201-214.

d'Haenens, L., Kokhuis, M., and Summeren, C. van (2002). ICTs in Dutch schools: Problems, prospects and promises. In M. Pendakur and R. Harris (Eds.), Citizenship and participation in the information age (pp.121-134). Aurora: Garamond Press.

d'Haenens, L., Beentjes, J. W. J., and Bink, S. (2000a). Mediabeleving van allochtonen in Nederland. Kwalitatief onderzocht. In Netherlands Press Fund (Ed.), Pluriforme informatie in een pluriforme samenleving. Knelpunten in de informatievoorziening van en voor etnische minderheden in Nederland, met bijzondere aandacht voor de persmedia [Multiform information in a multiform society. Bottlenecks in 
the information provision aimed at ethnic minorities in the Netherlands, with a special emphasis on the print media] (pp. 44-112). The Hague: Netherlands Press Fund.

d'Haenens, L., Beentjes, J. W. J., and Bink, S. (2000b). The media experience of ethnic minorities in the Netherlands: A qualitative study. Communications: The European Journal of Communication Research, 25(3), 325-341.

Heelsum, A. J. van (1997). De etnisch-culturele positie van de tweede generatie Surinamers [Ethnic-cultural position of the second generation of Surinamese]. Amsterdam: Het Spinhuis.

Linders, L. and Goossens, N. (2004). Bruggen bouwen met virtuele middelen [Building bridges with virtual tools]. In J. de Haan and O. Klumper (Eds.), Jaarboek ICT en samenleving: Beleid in praktijk (pp. 121-139). Amsterdam: Boom.

MCA Communication (2002). Computer- en internetgebruik onder Marokkanen, Turken en Surinamers [Computer and Internet use among Moroccans, Turkish and Surinamese]. Utrecht: MCA Communication.

Putnam, R. (2000). Bowling alone, the collapse and revival of civic America. New York: Simon and Schuster.

Veldkamp Marktonderzoek (1999). Mediagebruik etnische publieksgroepen - 1998. Een onderzoek onder Turkse, Marokkaanse, Surinaamse, Antilliaanse, Chinese en Molukse publieksgroepen van 18 jaar en ouder [Media use ethnic audience groups - 1998]. Amsterdam: Veldkamp Marktonderzoek.

Veldkamp Marktonderzoek (1998). Tijdsbesteding van mediagebruik allochtone jeugd 1997 [Media consumption ethnic minority youth - 1997]. Amsterdam: Veldkamp Marktonderzoek.

Veldkamp Marktonderzoek (1996). Media-onderzoek etnische groepen - 1995 [Media research ethnic groups - 1995]. Amsterdam: Veldkamp Marktonderzoek.

Waal, M. de (2003). Soms op de kaasmanier, soms op onze manier [Sometimes the cheese way, sometimes our way]. In H. Blanken and M. Deuze (Eds.), De mediarevolutie. 10 jaar www in Nederland (pp. 146-167). Amsterdam: Boom.

Wal, J. ter (2002). Racism and cultural diversity in the mass media. An overview of research and examples of good practice in the EU member states, 1995-2000. Vienna: EUMC. 